\title{
ROLA OJCA NA PODSTAWIE 20. HOMILII JANA ZŁOTOUSTEGO NA LIST ŚW. PAWŁA DO EFEZJAN
}

W problematyce rodzinnej poruszanej przez Jana Chryzostoma, kluczowym zagadnieniem są harmonijne relacje rodzinne, które są możliwe dzięki podziałowi obowiązków rodzinnych, wyznaczonych dla każdego członka rodziny. Temat ten pojawia się między innymi w 20. homilii na List św. Pawła do Efezjan ${ }^{1}$, w której autor komentuje tekst Ef 5, 22-24. Z tego względu w niniejszym opracowaniu postanowiono przeanalizować treści związane z rolą, jaką Chryzostom wyznacza ojcom rodzin ${ }^{2}$. Rola ojca w rodzinie wypływa z naśladowania Chrystusa. Jego relacja do żony (zwłaszcza szacunek dla niej) ma być budowana na relacjach Chrystusa do Kościoła, dlatego Chryzostom nazywa rodzinę „małym Kościołem”, porównując ją do Kościoła jako Ciała Mistycznego. Życie „małego Kościoła” ma być przeniknięte modlitwą oraz czytaniem Pisma Świętego.

1. Powołanie do odpowiedzialnej milości oraz podzial obowiązków. Bóg w swojej nieskończonej mądrości stworzył człowieka: mężczyznę i ko-

* Ks. mgr lic. Dem'yan Yatskov - wykładowca w Wyższym Seminarium Duchownym w Gródku Podolskim na Ukrainie, doktorant przy Katedrze Historii Kościoła w Starożytności Chrześcijańskiej w Instytucie Historii Kościoła i Patrologii na Wydziale Teologii Katolickiego Uniwersytetu Lubelskiego Jana Pawła II w Lublinie; e-mail: yatskovdominik@yandex.ru.

${ }^{1}$ Jan Chryzostom wygłosił 24 homilie na List do Efezjan. Są one dość zróżnicowane pod względem tematycznym. Autor artykułu dla opracowania tematu wybrał tylko homilię 20., która najpełniej ukazuje jego poglądy, jako duszpasterza, na temat rodziny oraz obowiązków męża jako głowy i ojca rodziny. Por. Joannes Chrysostomus, In epistulam ad Ephesios hom. 20, 1-9, PG 62, 135-150, tłum. M. Jurek: Św. Jan Chryzostom, O matżeństwie: homilia 20 na List do Efezjan, w: Św. Jan Chryzostom, O matżeństwie, wychowaniu dzieci i ascezie, BOK 19, Kraków 2002, 47-71.

${ }^{2}$ Zagadnienie roli ojca, jaką odgrywał w rodzinie było już przedmiotem badań uczonych. Z ważniejszych należy wymienić: A. Uciecha, Rola ojca $w$ procesie wychowania domowego na podstawie traktatu św. Jana Chryzostoma „O wychowaniu dzieci”, w: Dziecko w rodzinie i społeczeństwie. Starożytność-średniowiecze, red. J. Jundziłł, D. Żołądź-Strzelczyk, Bydgoszcz 2002, 205 218; B. Czyżewski, ,,Pater familias” i jego zadania wedtug św. Jana Chryzostoma, VoxP 29 (2009) t. 53-54, 205-221. Warto też zwrócić uwagę na bibliografie: Matżeństwo i rodzina w starożytności chrześcijańskiej [materialy bibliograficzne], S. Longosz, VoxP 5 (1985) t. 8-9, 449-507; Matżeństwo, rodzina i wychowanie w nauczaniu Jana Chryzostoma. Materiaty bibliograficzne, S. Longosz, VoxP 29 (2009) t. 53-54, 805-812. 
bietę, którzy wzajemnie od siebie zależą ${ }^{3}$ Mężczyzna dopełnia kobietę, a kobieta - będąc równą mężczyźnie - dopełnia go własną osobowością ${ }^{4}$ W tych relacjach przejawia się i wyraża godność człowieka.

Bóg Ojciec stwarzając człowieka - mężczyznę i kobietę, rozdzielił ich obowiązki oraz wyznaczył odpowiednie dla nich funkcje. Bóg stwarzając kobietę uczynił ją z żebra mężczyzny. Jednak nie dokonał tego z tego powodu - jak podkreśla Chryzostom - by mężczyzna nią gardził, albo żeby wywyższał się nad nią, lecz z tego powodu, by kobieta miała świadomość faktu, że będąc częścią ciała mężczyzny, powinna pamiętać o tym, że ma być mu poddana 5 . Wielkim złem według Antiocheńczyka jest bunt kobiety oraz nieposłuszeństwo mężczyźnie. Nic tak nie kształtuje relacji męża do żony, jak prawdziwa oraz rzeczywista akceptacja relacji Chrystusa do Kościoła. Ten ideał u Złotoustego pozostaje podstawowym właśnie dlatego, żeby jak najlepiej wytłumaczyć prawdzie ojcostwo mężczyzny w rodzinie ${ }^{6}$.

Dla zgody w rodzinie Pan Bóg ustanowił różne stopnie władzy, a całość aktywności człowieka podzielił na dwa wymiary: publiczny - wyznaczony przede wszystkim dla mężczyzn oraz prywatny - wyznaczony dla kobiet. Zatem do każdego mężczyzny należą obowiązki odnoszące się do życia publicznego, m.in. praworządność, ekonomia, służba wojskowa; do kobiet zaś odnoszą się prywatne obowiązki domowe, do których zalicza się przędzenie lnu, tkanie, przygotowanie posiłków, pilnowanie porządku w domu. Chryzostom zatem wyznacza kobietom prace domowe, zabrania zaś zarabiania pieniędzy poza domem. Żona powinna dbać o dom i rodzinę, i tym samym zwolnić mężczyznę od obowiązków domowych. Taki podział obowiązków, według niego, jest ustanowiony przez Boga, który zapewnia jedność oraz harmonię w relacjach między mężczyzną i kobietą7. W małżeństwie mężczyzna jest jakby królem, a żona - zarządcą. Do dzieci należy władza trzeciego stopnia, a do niewolników - władza czwartego stopnia ${ }^{8}$. Pan Bóg wyznaczył kobiecie mniejszą część obowiązków, ponieważ ona jest tylko „pomocą” dla mężczyzny (por. $\operatorname{Rdz} 2,18)^{9}$, chociaż jej udział jest potrzebny w wielu sprawach.

Żona pomaga mężowi prowadzić życie cnotliwe. Dzięki niej staje się on prawdziwym ojcem rodziny ${ }^{10}$. Ona troszczy się o sprawy domowe, czuwa

\footnotetext{
${ }^{3}$ Por. Joannes Chrysostomus, Sermo de caritate, PG 60, 773-776.

${ }^{4}$ Por. О. Паскуато, Миряни у Йоана Золотоустого. У Церкві, родині, громаді, Львів 2007, 102.

${ }^{5}$ Por. Joannes Chrysostomus, In epistulam ad Ephesios hom. 20, 1, PG 62, 136, BOK 19, 48: „«Żony niechaj będą poddane swoim mężom jak Panu» (Ef 5, 22). Dlaczego? Bo jeśli małżonkowie żyją w zgodzie, dzieci są dobrze wychowywane a domownicy przestrzegają porządku, wówczas budują się tym także krewni i przyjaciele, i sąsiedzi”.

${ }^{6}$ Por. tamże, PG, 62, 135-138.

${ }^{7}$ Por. Joannes Chrysostomus, In epistulam ad Ephesios hom. 20, 4, PG 62, 141; Паскуато, Миряни у Йоана Золотоустого, s. 103.

${ }^{8}$ Por. Joannes Chrysostomus, In epistulam I ad Corinthios hom. 34, 1, PG 61, 285-286.

${ }^{9}$ Por. tenże, Ad viduam iuniorem 4, PG 48, 604.

${ }^{10} \mathrm{~W}$ tym wypadku, Złotousty stawia męża w miejscu głowy, a żonę w miejscu ciała, ponieważ
} 
nad pracą domowników oraz służby domowej. Ze względu na to, że kobiety zajmowały się „,przyziemnymi” sprawami domowymi, Antiocheńczyk zaleca mężom, aby pomagali żonom w sprawach duchowych, w jakich mogą mieć nad nimi przewagę ${ }^{11}$.

Bóg wyznaczył mężczyznę na głowę rodziny. Chociaż w porządku stworzenia mężczyzna i kobieta zachowują równość osób, to jednak - co podkreśla Chryzostom - kobieta została stworzona z żebra Adama. Nie mogą mieć zatem takiej samej władzy. Dla zachowania porządku, harmonii i równowagi, ktoś musi być „wyższy”, a ktoś ,niższy”12.

W zamian za pokorę żony, mąż obdarza ją miłością ze względu na Jezusa Chrystusa, który bez miary ukochał jedyną Oblubienicę - Kościół - własne Ciało (por. Ef 5, 22). Tylko w takim porządku, żona powinna korzyć się przed mężem: nie ze względu na niego samego, ale ze względu na Chrystusa. Bóg w swoim odwiecznym zamyśle zechciał podporządkować kobietę mężczyźnie (por. Rdz 3, 16b), ponieważ tam gdzie występuje równość brakuje pokoju oraz równowagi. Z tej przyczyny kobieta, która nie poddaje się mężczyźnie, sprzeciwia się Bożym przykazaniom ${ }^{13}$.

Ze względu na Boga oraz przestrzeganie Jego przekazań, wady oraz różne słabości żon, mężowie powinni znosić cierpliwie. Chryzostom przekonuje mężów, żeby wady żon nie stawały się główną przyczyną oddalania ich ${ }^{14}$. Po-

tak zostało to przewidziane przez Bożą opatrzność. Por. Joannes Chrysostomus, In epistulam ad Ephesios hom. 20, 1, PG 62, 136, BOK 19, 49: „Rozważmy więc: mąż zajmuje miejsce głowy żona miejsce ciała. Wynika to też z tekstu: «Bo mąż jest głową żony, jak i Chrystus głową Kościoła: On Zbawca Ciała. Lecz jak Kościół poddany jest Chrystusowi, tak i żony mężom - we wszystkim» (Ef 5, 23-24). Mówiąc: «Mąż jest głową żony, jak i Chrystus Kościoła», Apostoł dodaje: «i On jest Zbawcą Ciała». Powiedział to, ponieważ głowa troszczy się o zdrowie ciała. Tak oto dla męża i żony uczynił on fundamentem miłość. Obojgu przypisał odpowiednie role: jemu panowanie i troskliwość, jej podporządkowanie".

${ }^{11}$ Por. tamże 20, 4, PG 62, 139.

${ }^{12}$ Por. Joannes Chrysostomus, In epistulam ad Ephesios hom. 20, 2, PG 62, 137; Паскуато, Миряни у Йоана Золотоустого, s. 131.

${ }^{13}$ Por. Joannes Chrysostomus, In epistulam ad Ephesios hom. 20, 2, PG 62, 136-138. Za cnotę najbardziej związaną z pokorą uważał Chryzostom - zgodnie z duchem ewangelicznym - łagodność,

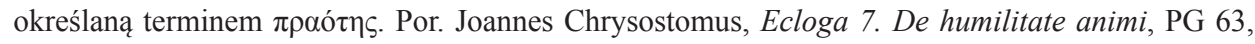
618. Zob. również: M. Szram, Cnota pokory w nauczaniu greckich Ojców Kościoła IV wieku, Lublin 2014, 88; tenże, Pokora $w$ walce z pycha - fundamentalny spór moralno-duchowy $w$ rozumieniu Ojców Kapadockich i Jana Chryzostoma, VoxP 33 (2013) t. 59, 531-345; tenże, Terminologia dotyczaca pokory i pychy w pismach greckich Ojców Kościoła IV wieku, VoxP 32 (2012) t. 58, 327-342; P. Szczur, Ideat doskonałości chrześcijańskiej wedtug Jana Chryzostoma, SSan 17 (2010) nr 1-2, 197-221; tenże, Zasady pedagogii św. Jana Chryzostoma w homiliach antiocheńskich, w: Czasy Jana Chryzostoma i jego pasterska pedagogika, red. N. Widok, Opolska Biblioteka Pedagogiczna 105, Opole 2008, 168-189; tenże, Problematyka społeczna w późnoantycznej Antiochii na podstawie nauczania homiletycznego Jana Chryzostoma, Lublin 2008, 321-323.

${ }^{14}$ Według Jana Chryzostoma najgorszą wadą jest chciwość pieniędzy. Dostatek materialny rodzinie ma zapewniać mąż. Por. Joannes Chrysostomus, In epistulam ad Ephesios hom. 20, 3, PG $62,138-139$. 
leca, aby we wszystkich trudnych okolicznościach małżonkowie zwracać się do Niego w gorących modlitwach. On okaże swe miłosierdzie i pomoże żonie pozbyć się wad, a męża obdarzy łaską prawdziwego ojcostwa, jako nagrodę za jego cierpliwość i pokorę. Dlatego mąż zajmuje miejsce głowy, żeby leczyć całe ciało, a żona właśnie dlatego kocha i ceni męża ${ }^{15}$.

Wiele razy kaznodzieja antiocheński prosi mężów, żeby traktowali żony z łagodnością i dobrocią. Cnotliwa oraz łagodna żona jest dla męża pociechą, siłą, radością oraz pomocą. Właśnie dlatego została ona dana mężowi przez Boga Stwórcę wszechświata jako osoba wolna i dla mężczyzny cenna ${ }^{16}$.

We własnym domu, żona zajmując się sprawami domowymi. Jeżeli zechce, może poświęcić wiele czasu na modlitwę oraz czytanie Pisma Świętego. Zatopiona w modlitwie, poświęcona pracy, ogarnięta ciszą oraz szacunkiem domowników, niczym pustelnik, przebywa w szkole mądrości. Tym samym zdobywa umiejętność pomocy mężowi w jego troskach o dom rodzinny. Dzieli jego troski oraz staje się jego doradczynią ${ }^{17}$.

Kierowanie domem, według Złotoustego, jest nie tylko przywilejem, ale sztuką nad sztukami ${ }^{18}$. Sporo miejsca kaznodzieja antiocheński poświęca obowiązkowi wychowania dzieci. Ojciec obdarzony władzą nauczyciela, jest powołany do tego, by ciągle formować siebie i stawać się coraz doskonalszym nauczycielem całego środowiska rodzinnego ${ }^{19}$.

Mężowie są ustanowieni, aby kierować małżonkami nie dlatego, żeby zaspokoić żądzę panowania i korzystać z przywileju bycia głową, ale dlatego, żeby troszczyć się i wyprzedzać wszystkich domowników w zdobywaniu cnoty. Kiedy inni domownicy, zwłaszcza żona, wyprzedzą męża w zdobywaniu cnót, wówczas przestaje on być głową ogniska rodzinnego ${ }^{20}$. W przekonaniu Jana Chryzostoma cnoty wznoszą wszystkich do pierwotnego piękna, którym wyróżniał się człowiek, kiedy został stworzony na obraz i podobieństwo Boże"21.

Mąż ze wszystkich sił powinien uczynkami, a nie słowami, dążyć do zdobycia cnót we własnym domu. Natomiast jego pomocnica, żona, nade wszystko powinna troszczyć się, żeby inni członkowie rodziny podejmowali trud dla osiągnięcie królestwa niebieskiego ${ }^{22}$. Pan Bóg dał człowiekowi ręce i nogi, obdarzył go rozumem, zdrowiem fizycznym, sympatią, darem mowy, żeby

\footnotetext{
${ }^{15}$ Por. tenże, Ad eos qui scandalizati sunt 22, PG 52, 523-524.

${ }^{16}$ Por. G. Fregni, Mitujcie się czule. Duchowość rodziny wedlug Ojców Kościoła, thum. D. Wandzioch, Kraków 2002, 32-33; Joannes Chrysostomus, In epistulam ad Ephesios hom. 20, 2, PG 62, 137.

${ }^{17}$ Por. Паскуато, Миряни у Йоана Золотоустого, s. 62, 64 і 130-131.

${ }^{18}$ Por. Joannes Chrysostomus, Ecloga de mulieribus et pulchritudine 14, PG 63, 661-662.

${ }^{19}$ Por. Паскуато, Миряни у Йоана Золотоустого, s. 130-132; J. Krykowski, Nauka o matżeństwie, rodzinie $i$ wychowaniu, w: Św. Jan Chryzostom, O matżeństwie, wychowaniu dzieci $i$ ascezie, s. 29.

${ }^{20}$ Por. Паскуато, Миряни у Йоана Золотоустого, s. 62-63.

${ }^{21}$ Por. Joannes Chrysostomus, In Matthaeum hom. 56, 5, PG 58, 555-556, tamże 11, 3, PG 57, 195-196.

${ }^{22}$ Por. Joannes Chrysostomus, Ecloga 2. De oratione, PG 63, 581.
} 
tym wszystkim mógł posługiwać się dla własnego dobra oraz dobra bliźnich, przede wszystkim w trosce o zbawienie dusz ${ }^{23}$. Życie według przykazań Bożych przynosi wielką korzyść dla domowników oraz daje im wewnętrzną satysfakcję. Wszyscy domownicy prowadząc uczciwe życie uwielbiają Boga wszechmogącego ${ }^{24}$.

2. Wyrozumiałość względem żony. W relacjach małżeńskich mąż i żona powinni praktykować samozaparcie się oraz całkowite wzajemne ofiarowanie się. Tym samym będą naśladować Chrystusa oraz ofiarują sobie nawzajem najwierniejszą sympatię i miłośćć ${ }^{25}$.

Antiocheńczyk stawia też pewne wymagania wobec mężów, gdyż wstydliwy, czyli cnotliwy mąż, wnosi do domu harmonię oraz poczucie bezpieczeństwa wszystkich domowników ${ }^{26}$. Poleca, aby swoim żonom dawali to, czego zapragną oraz byli wobec nich wyrozumiali i cierpliwi ${ }^{27}$. Kaznodzieja zachęca mężów, żeby nie bali się kochać żon oraz podkreśla, żeby nie chlubili się pokorą małżonek. Jednocześnie miłość męża nie powinna stać się okazją do zuchwalstwa ze strony żony ${ }^{28}$. Aby żona korzyła się przed mężem jak przed Panem, powinien on troszczyć się o nią jak Chrystus opiekuje się Kościołem² ${ }^{29}$. Żonę trzeba szanować, chwalić, poświęcać jej swą uwagę i czas, podziwiać, a w domu oddawać jej przewagę i stawiać ją na pierwszym miejscu. Wówczas żona nie będzie miała okazji do pokus, a inni mężczyźni nie będą mieli dla niej żadnego znaczenia ${ }^{30}$. Mąż powinien bez narzekań przyjmować cierpienia, bóle, niebezpieczeństwa, i znosząc to wszystko, być gotowym nawet do oddania życia za żonę, potomstwo i rodzinę. Nie istnieje mocniejsza więź od przymierza pomiędzy mężczyzną i kobietą, wyrażającego się w sakramencie małżeństwa ${ }^{31}$.

Mąż będąc głową rodziny, powinien własnym przykładem życia uczyć żonę - własne ciało: łagodności, cnotliwości oraz umiarkowania w relacji do dóbr i wartości materialnych. $Z$ wielkim szacunkiem do płci kobiecej, która według Chryzostoma jest słabszą od męskiej, zachęca kaznodzieja, żeby mąż ukazywał żonie, iż prawdziwą ozdobą jest skromność i prawda, że ubóstwo

${ }^{23}$ Por. tenże, In Matthaeum hom. 78, 3, PG 58, 705-706.

${ }^{24}$ Por. tenże, In Joannem hom. 57, 3, PG 59, 310.

${ }^{25}$ Por. Паскуато, Миряни у Йоана Золотоустого, s. 100-101.

${ }^{26}$ Por. Joannes Chrysostomus, In epistulam ad Ephesios hom. 20, 1-4, PG 62, 135-141.

${ }^{27}$ Por. tamże 20, 4, PG 62, 139-141.

${ }^{28}$ Por. tenże, In epistulam ad Collosenses hom. 10, 1, PG 62, 365-366.

${ }^{29}$ Por. tenże, In epistulam ad Ephesios hom. 20, 2-4, PG 62, 136-141; Fregni, Milujcie sie czule, s. 36.

${ }^{30}$ Por. tamże 20, 1-4, PG 62, 135-141.

${ }^{31}$ Por. C. Scaglioni, Ideale coniugale e familiare in San Giovanni Crisostomo, w: Etica sessuale e matrimonio nel cristianesimo delle origini, ed. R. Cantalamessa, Milano 1976, 355; Паскуато, Миряни у Йоана Золотоустого, s. 100-101. 
i niedostatek materialny nie jest złem, zaś bogactwo oraz miłość do pieniędzy jest wielkim niebezpieczeństwem.

Po zawarciu małżeństwa mąż i żona nie mają więcej osobnej własności, lecz tylko wspólną. Mąż - głowa rodziny, nie mając władzy nad własnym ciałem, tym bardziej nie ma władzy nad tym wszystkim, co do niego wcześniej należało ${ }^{32}$. Mężczyzna, który uważa, iż małżeństwo może być źródłem zysku, i dlatego żeni się z bogatą kobietą, bierze sobie zamiast „pomocnicy” władczynię, która zniewalając go, czyni z niego niewolnika ${ }^{33}$. Chęć zysku, według Złotoustego, przysparza wiele kłopotów ${ }^{34}$. Bogata oraz apodyktyczna małżonka, często zajmuje miejsce głowy, i upokarzając męża, narusza porządek ustanowiony przez Boga Stwórcę ${ }^{35}$.

Nawet w wypadku braku miłości męża do żony i żony do męża, małżonkowie powinni zachowywać wierność Bogu i jego przykazaniom ${ }^{36}$. Pan Bóg nie dlatego nakazał mężczyźnie opuścić rodziców, żeby krzywdzić małżonkę, lecz po to, by się nią opiekował i troszczył o nią. Dlatego przemoc względem żony Chryzostom mocno piętnuje ${ }^{37}$. Kłótnia i wrogość w domu rodzinnym rozszerza się na całe społeczeństwo. Dla małżonków, którzy są pozbawieni wyrozumiałości oraz harmonii - dobrobyt, bogactwo, rozkosze oraz władza, nie przynoszą żadnego pożytku. Dzięki harmonii oraz wzajemnej pomocy, pomiędzy małżonkami rodzi się wiele dobra. Dlatego w swych homiliach Jan Chryzostom niemalże błaga żony, żeby mężowie byli dla nich największym skarbem, oraz żeby dla mężów żony była jak najbardziej pożądanymi osobami ${ }^{38}$.

Żeby zdobyć uznanie przed Bogiem oraz wzmocnić miłość i przychylność męża, żona powinna ozdabiać siebie cnotami: skromnością, łagodnością, pokorną cierpliwością, miłością i szacunkiem dla męża. Inne ozdoby, zwłaszcza zrobione $\mathrm{z}$ drogocennych kamieni nie przynoszą radości. Cnota zdobyta na ziemi czyni małżonków bezpiecznymi, bo wiedzie ich do nieba ${ }^{39}$. Za przykład prawdziwej kobiecości Złotousty stawia biblijne postaci kobiet: Sarę, Rebekę oraz Liję. Według niego były one pełne przyrodzonego oraz duchowego piękna ${ }^{40}$.

Jan Chryzostom poro miejsca poświęca także modlitwie, ponieważ przy jej pomocy człowiek może pomóc sobie oraz bliźnim w zdobywaniu cnoty i otrzymaniu nagrody od Boga. Mąż pomaga żonie i troszczy się o jej duszę nie dlatego, aby jemu się podobała, ale przede wszystkim Bogu ${ }^{41}$. Złotousty

\footnotetext{
${ }^{32}$ Por. tenże, In Epistolam I ad Corinthios hom. 19, 1, PG 61, 151-152.

${ }^{33}$ Por. Krykowski, Nauka o matżeństwie, s. 20.

${ }^{34}$ Por. Joannes Chrysostomus, In epistulam ad Ephesios hom. 20, 2-4, PG 62, 136-141.

${ }_{35}$ Por. tenże, De virginitate 53, PG 48, 576; tenże, Quales ducendae sint uxores 4, PG 51,

${ }^{36}$ Por. tenże, In epistulam ad Ephesios hom. 20, 2-4, PG 62, 136-141.

${ }^{37}$ Por. tenże, De Eleemosyna sermo 4, PG 51, 266-267.

${ }^{38}$ Por. tenże, Non esse desperandum 6-7, PG 51, 369-370.

${ }^{39}$ Por. Паскуато, Миряни у Йоана Золотоустого, s. 88-89.

${ }^{40}$ Por. Joannes Chrysostomus, In Matthaeum hom. 30, 3, PG 57, 361-362.

${ }^{41}$ Por. tenże, In epistulam ad Ephesios hom. 20, 2-4, PG 62, 136-141.
} 230-231. 
nawet radzi mężom, żeby stawiali żonom więcej wymagań niż one same sobie postawiły.

Żona jest częścią ciała męża, stąd zasługuje na szczególną miłość z jego strony. Żadne wykroczenie, żadna wada nie powinna naruszyć tej miłości ${ }^{42}$. Tylko miłość stanowi wartość sakramentu małżeństwa ${ }^{43}$. Jak Chrystus kocha Kościół i uświęca go, tak samo i mąż, kiedy jest pełen miłości Chrystusowej, podobnie postępuje wobec żony ${ }^{44}$.

Nawet wtedy, kiedy żona różni się od swego męża, nie jest to wielka różnica, ponieważ Kościół nie różni się od Zbawiciela, gdyż jest Jego Mistycznym Ciałem $^{45}$. Dlatego prawdziwy mąż jest wyrozumiały i świeci przykładem miłosierdzia względem żony, nie dokucza jej i nie wymagać od niej za wiele ${ }^{46}$.

Życie zgodne z wolą Boga, jest główną treścią 20. homilii Jana Chryzostoma na List do Efezjan ${ }^{47}$. Dlatego małżeństwo, które będzie cechowało się w życiu codziennym prawdziwą bojaźnią Bożą, otrzyma od Niego wielką nagrodę, a szukając przede wszystkim dóbr duchowych, czyli wiecznych, otrzyma i te, które są potrzebne w życiu doczesnym ${ }^{48}$.

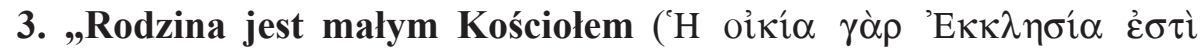

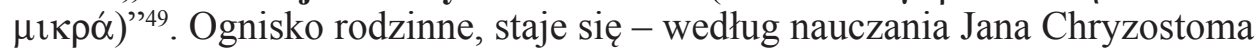
- „małym Kościołem” tylko wtedy, gdy mężowie, których głową jest sam Jezus Chrystus, wyposażeni w potrzebne zalety, są zdolni dobrze kierować własnymi domami ${ }^{50}$. Mąż jest powołany przez Boga do tego, by godnie i uczciwie

\footnotetext{
${ }^{42}$ Por. tenże, Quales ducendae sint uxores 2-3, PG 51, 226-230.

${ }^{43}$ Por. Паскуато, Миряни у Йоана Золотоустого, s. 101.

${ }^{44}$ Por. Joannes Chrysostomus, Quales ducendae sint uxores 2-3, PG 51, 226-230.

${ }^{45}$ Por. Fregni, Mitujcie się czule, s. 37.

${ }^{46}$ Por. Joannes Chrysostomus, In epistulam ad Ephesios hom. 20, 2-4, PG 62, 136-141; tenże, In Matthaeum hom. 30, 2-3, PG 57, 359-360; Fregni, Mitujcie się czule, s. 35-36.

${ }^{47}$ Por. Паскуато, Миряни у Йоана Золотоустого, s. 63.

${ }^{48}$ Por. Joannes Chrysostomus, In epistulam ad Ephesios hom. 20, 2-4, PG 62, 136-141.

${ }^{49}$ Tamże 20, 6, PG 62, 143. Na temat rozumienia rodziny jako „kościoła domowego” istnieje
} bogata literatur. Z nowszych opracowań warto wymienić następujące prace: S. Longosz, Rodzina wczesnochrześcijańska kościołem domowym, RT 51 (2004) z. 10, s. 27-56; tenże, Rodzina kościołem domowym w myśli św. Jana Chryzostoma, VoxP 29 (2009) t. 53-54, 312; N. Widok, Christian Family as Domestic Church in the Writtings of St. John Chrysostom, „Studia Ceranea” 3 (2013) 167-175.

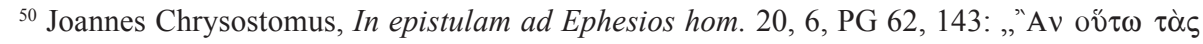

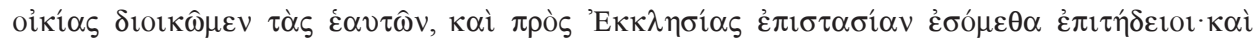

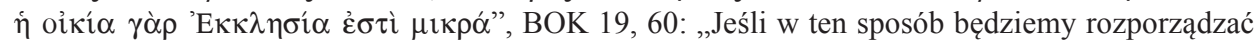
swoim domem, staniemy się również godni przewodzenia Kościołowi. Rodzina bowiem jest małym Kościołem”. Паскуато, Миряни у Йоана Золотоустого, s. 105. Joannes Chrysostomus, In epistulam I ad Timotheum hom. 10, 2, PG 62, 549, tłum. T. Sinko, w: Św. Jan Złotousty, Homilie na Listy Pasterskie św. Pawta i na List do Filemona (Tym. I, II. Tyt. Filem.), Kraków 1949, s. 105: „Albowiem Kościół jest jakoby wielki dom. I jak w domu są synowie, żona, słudzy, a mąż ma władzę nad wszystkimi, tak i w Kościele nie ma nic innego, jak to samo: synowie, niewiasty, słudzy. A jeśli przełożony Kościoła ma wspólników rządu, to także w domu mąż ma za wspólniczkę żonę. 
zarządzać całym domem ${ }^{51}$. Dlatego w pierwszych wiekach chrześcijaństwa pisarze kościelni przekonywali heretyków, iż małżeństwo jest świętym związkiem mężczyzny i kobiety ${ }^{52}$.

Należyta troska o rodzinę, zwłaszcza o żonę i dzieci, przysposabia też męża do odpowiedzialności za nich przed Bogiem ${ }^{53}$. Gdy mąż jest dobry i mądry, w jego domu nie będzie bałaganu, a ten, kto potrafi zaprowadzać harmonijne relacje wśród domowników, jest zdolny kierować nawet wspólnotą wiernych (czyli Kościołem), ponieważ dom to Kościół w miniaturze. Ten, kto potrafi właściwie kierować sprawami materialnymi, ten też dobrze pokieruje sprawami duchowymi ${ }^{54}$.

Małżonkowie, jako członkowie Kościoła, bezpośrednio uczestniczą w relacji Chrystus - Kościół. Podobnie jak w Kościele, tak i w rodzinie panuje ustrój hierarchiczny. Mąż jest głową rodziny. Wynika to z obrazu Kościoła - Ciała Mistycznego, którego Głową jest Chrystus (por. Ef 5, 22-24), a jego powołanie bycia nauczycielem, wynika z urzędu biskupa, prawdziwego ojca wspólnoty wiernych ${ }^{55}$. Dobry zarządca domu zdobywa domowników do współudziału w trosce o zbawienie dusz przez cnotę pokory oraz zaprowadzaną w życiu rodzinnym harmonię ${ }^{56}$.

Tak jak duchowni będą odpowiadać przed Bogiem za zbawienie dusz powierzonych im wiernych, tak głowa rodziny odpowie przed Stworzycielem życia, za wszystkich domowników, jakimi zarządza na ziemi ${ }^{57}$. Dlatego głowa rodziny, według porad kaznodziei z Antiochii, bardziej będzie troszczyć się nie o dobra materialne, lecz o to, żeby przedstawić Bogu jako święte dusze tych, których On mu powierzył w doczesności.

Żona może być pomocna mężowi w sprawie zbawienia duszy, jeżeli będzie przykładem skromności, łagodności, cierpliwości, jeżeli nie będzie zbytnio przywiązana do pieniędzy oraz rzeczy materialnych, kiedy będzie wspierać małżonka i za nic będzie mieć życie ziemskie, a nade wszystko będzie umiała żyć zgodnie z nauką Pisma Świętego, ukazując swą cierpliwością życiową mądrość. Związek małżeński jest dla męża szkołą świętości i zdobycia doskonałości oraz środkiem zbawienia wszystkich członków rodziny ${ }^{58}$. Dlatego

\footnotetext{
- «Tak, ale czy w Kościele trzeba się troszczyć o wyżywienie wdów i dziewic?» - Ma i w domu mąż niewolników, córki. Zresztą nawet łatwiej jest rządzić domem. A kto nim dobrze nie zarządza, jak będzie mógł rządzić Kościołem?”.

${ }^{51}$ Por. Паскуато, Миряни у Йоана Золотоустого, s. 106 і 130-131.

${ }^{52}$ Por. F. Drączkowski, Świętość matżeństwa i rodziny wedlug Klemensa Aleksandryjskiego, VoxP 5 (1985) t. 8-9, 95-125.

${ }^{53}$ Por. Joannes Chrysostomus, In epistulam ad Ephesios hom. 20, 6, PG 62, 143.

${ }^{54}$ Por. tenże, In epistulam ad Titum hom. 4, 2, PG 62, 683-684.

${ }^{55}$ Por. Krykowski, Nauka o matżeństwie, s. 30; Fregni, Mitujcie się czule, s. 46.

${ }^{56}$ Por. Joannes Chrysostomus, In Matthaeum hom. 77, 6, PG 58, 709-710; Паскуато, Миряни у Йоана Золотоустого, s. 133.

${ }^{57}$ Por. Fregni, Mitujcie się czule, s. 46.

${ }^{58}$ Por. Krykowski, Nauka o matżeństwie, s. 28; Fregni, Miłujcie się czule, s. 46.
} 
mąż, który został biskupem w Kościele, jest z urzędu powołany do tego, by być przykładem życiowej mądrości oraz uosabiać w sobie łagodność i gorliwość w uczeniu się tekstów Pisma Świętego ${ }^{59}$.

Mąż względem żony spełnia rolę nauczyciela ${ }^{60}$. Żona nie może nauczać w Kościele, jednak może być nauczycielką w Kościele domowym. Kobieta w podeszłym wieku powinna nauczać kobiety młodsze od siebie i być dla nich przykładem cnót. Według Złotoustego, nie chodzi tu tylko o córki, lecz o wszystkie kobiety młodsze od niej wiekiem ${ }^{61}$. Mąż, który w domu przekazuje zbawienne treści, które usłyszał w kościele, proroctwa proroków oraz nauczanie apostołów, czyni żonę bardziej cnotliwą, syna mądrzejszym, przyjaciela bardziej otwartym, a sługę bardziej wiernym, ponieważ proponuje im wszystkim ucztę duchową przepełnioną naukami o cnotach ${ }^{62}$. Członkowie Kościoła domowego karmią się nie tylko pokarmem materialnym, lecz także pokarmem duchowym - Słowem Bożym ${ }^{63}$. Po takiej podwójnej uczcie, dom napełnia się atmosferą radości, a sen jest bardziej zrównoważony, pełen pięknych i przyjemnych widoków ${ }^{64}$.

Lekturze Pisma Świętego powinna towarzyszyć modlitwa, np. po spożyciu posiłku -wspólny śpiew psalmów przy rodzinnym stole. W ten sposób dom przemienia się w kościół, do którego złe duchy nie mają odwagi zaglądnąć. Modlitwa jest najlepszym środkiem i lekiem przeciwko wszystkim namiętnościom, zwłaszcza w piciu wina ${ }^{65}$. Modlitwa pomaga powstrzymać język od gadulstwa. Chryzostom często zachęcał, by codziennej pracy towarzyszyła modlitwa i śpiew psalmów oraz pieśni pobożnych. Radzi nieustannie wielbić Boga, nawet w nocy, a w modlitwach żarliwie błagać Go i wypraszać potrzebne łaski ${ }^{66}$. Noc nie jest stworzona tylko dla wypoczynku ciała, lecz także dla duchowego wzmocnienia. W nocy nikt człowiekowi nie przeszkadza w modlitwie. W tym czasie umysł człowieka jest spokojniejszy, wolny od niepotrzebnych kłopotów, panuje w nim cisza. Ojciec Kościoła podkreśla, że wielkim brakiem rozsądku oraz niewdzięcznością jest, by sześć dni w tygodniu poświęcać troskom doczesnym, a tylko jeden dzień (a nawet tylko jedną jego część) poświęcać sprawom duchowym7 ${ }^{67}$. Pan Bóg mógł przecież zare-

${ }^{59}$ Por. Joannes Chrysostomus, In epistulam I ad Timotheum hom. 9, 1-2, PG 62, 543-548; Паскуато, Миряни у Йоана Золотоустого, s. 131; Krykowski, Nauka o matżeństwie, s. 32.

${ }^{60}$ Por. Паскуато, Миряни у Йоана Золотоустого, s. 132.

${ }^{61}$ Por. Joannes Chrysostomus, In epistulam ad Titum hom. 4, 2, PG 62, 683.

${ }^{62}$ Por. tenże, De paenitentia $6,1, \mathrm{PG} 49,313$.

${ }^{63}$ Por. Joannes Chrysostomus, In Genesim ser. 6, 2, PG 54, 607, tłum. S. Kaczmarek, ŹMT 45, Kraków 2008, 95: „Zachowajmy te treści i wróciwszy do domu zastawmy dwa stoły: stół pokarmów i stół wykładu. Niech mąż przedstawi to, co tu [tj. w kościele] zostało powiedziane, a żona niech się uczy, niech słuchają także dzieci, i nawet niewolnicy niech nie będą pozbawieni tego wykładu".

${ }^{64}$ Por. Паскуато, Миряни у Йоана Золотоустого, s. 77-78 і 146-147.

${ }^{65}$ Por. Krykowski, Nauka o małżeństwie, s. 31.

${ }^{66}$ Por. Паскуато, Миряни у Йоана Золотоустого, s. 77-78 і 107.

${ }^{67}$ Por. Fregni, Mitujcie się czule, s. 53. 
zerwować dla siebie większą część dni w tygodniu, jednak tego nie uczynił. Jednak człowiek nawet tego jednego dnia w tygodniu nie chce poświęcić Panu Bogu. Z tego względu Chryzostom nazywa ,świętokradcami” tych, którzy „wykradają" Bogu czas tego jednego, uświęconego przez Pana dnia ${ }^{68}$.

Jednym z poważniejszych problemów związanych z funkcjonowaniem małżeństwa w czasach Jana Chryzostoma było uczęszczanie mężczyzn do teatru. Nasz autor mówił, że przyczyną chodzenia mężczyzn na przedstawienia teatralne jest napięta sytuacja $\mathrm{W}$ domu. $\mathrm{W}$ teatrach aktorzy odgrywali bardzo śmiałe sceny miłosne, stąd widowiska nazywał on ,szkołą nierządu" ${ }^{69}$. Z tego względu zachęcał, aby wierni chodzili do kościoła, a nie do teatru, ponieważ uczestnictwo w świętej liturgii i spędzenie czasu w świątyni przynosi spory pożytek ${ }^{70}$. W innym miejscu przekonywał o korzyściach płynących z modlitwy, zwłaszcza wtedy, kiedy jest praktykowana wspólnie i zanoszona do Boga razem z kapłanami. Modlitwa jest matką mądrości dlatego człowiek odnosi z niej pożytek duchowy. Dlatego radził, aby mężczyźni nieustannie trwali na modlitwie i praktykowali ją rano oraz wieczorem. Modlitwa pomaga godnie przeżyć życie ziemskie, ratuje do kłopotów i przyszłych cierpień oraz pomaga osiągnąć życie wieczne ${ }^{71}$.

\section{$* * *$}

Podsumowując poglądy Jana Chryzostoma na temat roli mężczyzny jako ojca rodziny, warto zauważyć, iż wielki kaznodzieja antiocheński bardzo pozytywnie wypowiada się o zadaniach męża i ojca rodziny. Obowiązki rodzinne, które powinien realizować, mają swe źródło w bojaźni Bożej i szacunku do żony, zaś sam szacunek do małżonki jako cnota życia rodzinnego, wywodzi się z miłości od słuchania Słowa Bożego. Tylko taki mąż, jako głowa rodziny, prowadzony miłością nadprzyrodzoną (pochodzącą od Boga, który kocha człowieka), jest zdolny do poszanowania żony, jako własnego ciała. Ponieważ małżonkowie są osobami - myślącymi i zdolnymi do miłowania, to są równi sobie. Ta równość wyrażająca się w porządku realizacji właściwych sobie zadań, zależy od wierności męża i chęci zdobywania cnót.

${ }^{68}$ Por. Joannes Chrysostomus, De baptizmo Christi 4, PG 49, 372, thum. W. Kania, w: Kazania i homilie na święta Pańskie i Maryjne, red. L. Gładyszewski, STCh 1, Lublin 1976, 85: „Gdy spożyjesz zwykły pokarm, wstawszy od stołu odmawiasz modlitwę, a gdy ci dano pokarm duchowy, który o wiele przewyższa wszelkie widzialne i niewidzialne stworzenie, choć jesteś człowiekiem, czyli słabą istotą, nie chcesz słowem i czynem złożyć dziękczynienia”. Tymi słowami Antiocheńczyk zwraca też uwagę na usposobienie duchowe oraz zachowanie tych, którzy mają przyjąć Komunię świętą.

${ }^{69}$ Por. Krykowski, Nauka o matzeństwie, s. 22.

${ }^{70}$ Por. Joannes Chrysostomus, De paenitentia 6, 2, PG 49, 314.

${ }^{71}$ Por. tenże, In Matthaeum hom. 19, 2, PG 57, 275-276; tamże 23, 5, PG 57, 305-306; tenże, De oratione PG 62, 737-740. 


\title{
THE ROLE OF FATHER ACCORDING TO THE JOHN'S CHRYSOSTOM $20^{\mathrm{TH}}$ HOMILY ON EPHESIANS
}

\begin{abstract}
(Summary)
The division of family responsibilities, which are designed for each household member and harmonious family relationships are one of the most important keynotes of St. John's Chrysostom preaching. In order to explain this issue he wrote homily on the Epistle to the Ephesians. According to it, the role of father in household is based on following Christ. Husbant's relationship to his wife, especially respect for her, should be built by analogy to the relationship between Christ and the Church. The author calls the family a "small church", comparing it to the Church as the Mystical Body. Living of the "small Church" is permeated with prayer and Holy Scripture reading. Firstly husband - the head of the family, performs the following Christian actions: reads inspired texts, strengthens himself by the sacrament of the Eucharist (that is, he takes the Holy Communion). And thanks to that going to church and celebrate the Lord's Day, are the usual practice of all members of the parva Ecclesia.
\end{abstract}

Słowa kluczowe: ojciec, rodzina, mąż, żona, mały Kościół.

Key words: father, family, husband, wife, small Church. 
